\title{
Great Mentors: Robert Jervis, Bruce Bueno de Mesquita, and Peter Katzenstein
}

\author{
Rose McDermott, Brown University
}

\begin{abstract}
Editor's Note: This piece is part of the Committee on the Status of Women in the Profession (CSWP) series of short pieces by senior scholars, discussing different aspects of their own careers, designed both to publicly thank their mentors and to provide concrete illustrations of how important and ongoing good mentoring can be. The CSWP encourages other scholars to send us descriptions of their mentor experiences.
\end{abstract}

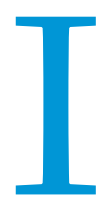

have been extremely blessed in my life to have benefitted from some amazing mentors and friends in both psychology (most notably, Amos Tversky, Phil Zimbardo, and Leda Cosmides) and political science. Inspired by the occasion of Robert Jervis' festschrift, which importantly does not signal his imminent retirement, I was prompted to take advantage of this opportunity to express my deep and abiding appreciation for his advice and guidance over the years. In keeping with Kristen Monroe's model of three, I also reflect here on the critical roles that two additional mentors, Bruce Bueno de Mesquita and Peter Katzenstein, have had on my career and my life.

\section{ROBERT JERVIS}

At the end of a day of papers presented by Jervis's students at Columbia on the occasion of his seventieth birthday, I found the commentary by Tom Schelling and the response by Bob Jervis particularly touching. Schelling noted that in a recent meeting designed to bring the old guard and fresh faces together, any observer who listened to the discussion without seeing the faces would certainly have pegged Bob as a "fresh face," not only because of the creativity of his ideas and the indefatigable energy he constantly displays, but also because of his continual curiosity, interest, and love of learning. In response to these comments, Jervis spoke about the important influence that Schelling had had on his own career as well as the significant, yet differing, influence of others such as Glenn Synder, Arnold Wolfers, and McGeorge Bundy. I was particularly struck when he said he did not like the term "mentor," because it suggested a one-way relationship,

Rose McDermott is a professor of political science at Brown University. A 2008-09 Fellow at the Center for Advanced Studies in the Behavioral Sciences at Stanford University, McDermott has also taught at Cornell and UCSB and held fellowships at Harvard's Olin Institute for Strategic Studies and Harvard's Women and Public Policy Program. She will be a fellow at the Radcliffe Institute for Advanced Study at Harvard University during academic year 2010-11. She can be reached at rose_mcdermott@brown.edu. whereas in his view and experience, good teaching and advising always involved a reciprocal relationship of learning and sharing. While I personally doubt that Jervis has learned nearly as much from me as I from him over the years, I did not question the sincerity of his statement or what it reflects of his fundamentally egalitarian approach to merit and scholarship.

I have now known Bob Jervis longer than anyone else with a continuing presence in my life except for my mother. He met me as a veritable child and has continued to befriend and instruct me into middle age. I could tell endless stories about kind words said or generous deeds done by Bob Jervis toward me. But I will restrict myself to a couple of the earliest and most important lessons he conveyed. I clearly recall my first day in graduate school at Columbia when I waited outside Jervis's door, second in line after Sue Peterson, to see Jervis during his office hours. It was 9:57 and office hours started at 10:0o. Sue knocked on the door. He came to the door, opened it, said, "I am not open for 3 minutes," and shut the door. At the time, I thought, "What can someone possibly accomplish in 3 minutes?" Now, of course, having been on the other side of that situation myself a million times, I realize that I learned three of the most important lessons I could ever learn as an academic in that first minute: set your boundaries clearly and appropriately; prioritize your time, because it is your most, and sometimes your only, valuable resource; and treat your students as adults capable of taking care of themselves, responsible for their own actions and decisions, and not as children who need to have their hands held.

After a year at Columbia, I returned to Stanford to work with Amos Tversky, about whose Prospect Theory I wrote my dissertation. At Stanford, I had a very hard time finding someone in the political science department who was willing to supervise a dissertation in political psychology. I received a letter saying that if I did not find a new dissertation topic or someone to support my existing topic, I would have to leave the program. I took a year's leave and went to work for the Dance Program of the New York State Council on the Arts. One day, out of the blue, Jervis called me on the phone, probably the first and only time that ever happened, ostensibly to ask me for a citation I knew he must already know. At the end of the conversation, he said to me, "Now, remind me, am I on your committee or not?" His offer came like water to a desert. I had a true moment of moral quandary, when I considered lying, out of desperation. But I had too much respect for Jervis, and I knew I did not want to start such a 
significant relationship with a lie. So I said, "No, but I would be grateful and honored if you would be willing to serve in that capacity." He said, "Fine," and hung up the phone. And that was that. I sat at my desk, surrounded by the best artists in New York City, and I sobbed. He had saved my career, for the first time, but not the last.

When I experienced a block trying to finish my dissertation, I talked to Bob and grudgingly and reluctantly admitted my failing. He said to me, "The worst dissertation ever completed is infinitely better than the best dissertation never finished." I took those words to heart, wrote them out in nice calligraphy, and taped them to my computer. Those words motivated me to finish then and continue to encourage me in a different way to this day.

When I returned to Stanford, the graduate bureaucracy was not as enamored of Jervis as I was and said they were not sure he would be an "acceptable" chair. They asked for a copy of his CV to evaluate his credentials. In one of the most embarrassing moments of my life, I called Bob, told him what had happened, and, cringing, asked if he could send me a copy of his CV. This was back in the old days, when documents had to be copied and sent by snail mail. Luckily, he laughed and said, "Ah, yes, bureaucrats. I will send you the long copy." Several days later, I walked into the graduate division office with a 55-page $\mathrm{CV}$, and they asked me what they were supposed to do with such a "doorstop." On that day, I learned the next two most important lessons in academics: create an impenetrable fortress of work, brick by brick, if necessary, and always treat yourself with a sense of humor.

In that spirit, recognizing that I write this acknowledgment under the auspices of the Committee on the Status of Women in the Profession, I will end my public ruminations about Bob Jervis with a joke that is also true. I always said that the most reassuring thing about Jervis was that if you asked him if I was male or female, he would look up, say, "Gee, I don't know," and toss a coin. I always knew that he never, ever held me to a different standard, expecting more or less or different because I was a woman. I always knew that I would be evaluated on merit, nothing more, nothing less. In this world, that attitude represents an exceptional gift. There are no words that can begin to express the depth of my gratitude and appreciation for that approach and that recognition.

\section{BRUCE BUENO DE MESQUITA}

I first met Bruce when he came to teach a class in Judy Goldstein's international relations theory class when I was in graduate school at Stanford. He did the funniest set of mimics I had ever seen in my life, and I instantly liked him enormously, even though, as a psychologist, I did not necessarily agree with his theoretical approach to political science. He was at Hoover at the time, and the following year, I took a graduate class he taught through sociology with five other students. This was before rational choice became a prominent model in international relations. In one class, Jane Holl said, "So, what you are telling us is that your model is a dessert topping and a floor wax all in one?" And, without missing a beat, Bruce replied, "With a cherry flavored mop."

After I finished graduate school, I had a National Institute on Drug Abuse Postdoctoral Fellowship in treatment outcome research at the San Francisco Department of Veterans' Affairs (VA), through the University of California-San Francisco department of psychiatry. In reality, I was running the methadone maintenance clinic for about six hundred heroin-addicted veterans. I had applied for jobs for two years, receiving one interview but no offers each year. I was becoming extremely discouraged and considering what else I might do when I accidentally ran into Bruce in the basement cafeteria of the business school at Stanford one day at lunch. He asked me how I was, I relayed my plight, and he looked at me and said, "Why haven't you asked me for a letter?" I stared at him, shocked, and said, honestly, "I didn't know I could. You were not on my committee. My work is different from yours." He smiled at me and said, "All the more reason for my support to help you. You took classes from me. You talk to me about your work. I know your work. There is no reason I should not write you a letter." I was struck and deeply touched by Bruce's catholic willingness to nurture and support someone whose own work was not only not in his area, but often ran in clear counter-distinction to his own arguments. I have always found the depth of his personal loyalty an inspiring model that I strive to emulate. The following year, I had two interviews and received both offers. I often wondered if that outcome had much less to do with my personal promise and much more to do with the fact that the relevant committees could not believe that both Bob Jervis and Bruce Bueno de Mesquita, two exceptional scholars known for very different kinds of work, came out in support of the same person. But their endorsement reflects much more about the generosity, breadth, and depth of their intellects than about any talents or skills I may possess.

Again, I could tell many stories about the myriad ways in which Bruce's help and support made my life vastly better, but I will confine myself to two of the most important lessons he taught me. First, I was always struck by how generous Bruce was in the time he offered to graduate students, but I also noted how hard he worked to ensure they received adequate financial support as well, including money for summer research. When I asked him about this, he told me a story about how Donald Stokes had supported him early in his career, what a difference that made for him, and how important even relatively minor amounts can be for a struggling graduate student. Through Bruce, I learned that the best tribute to kindness often lies not in trying to find a way to pay it back, but rather in working to replicate it in paying it forward in whatever way we can. Second, he always said, "There are two kinds of scholars: those who read, and those who write. Don't let the former imperative undermine your ability to accomplish the latter goal." Coming from someone who reads as widely and deeply as anyone I have ever encountered, I learned an important lesson regarding the appropriate balance between standing on the shoulders of giants and standing on my own two feet.

\section{PETER KATZENSTEIN}

Peter Katzenstein was not on my dissertation committee, but his influence on my intellectual growth and development has been so nuanced and profound, both in process and substance, that I consider him a mentor. I believe his inclusion is important because it illustrates the ways in which our learning continues throughout life and how those who come before us can share their knowledge and experience in ways that make our own paths clearer and lighter, if not easier. Peter was the first person to give me a job. He reminds me that the entire department voted me the position, but my subjective experience hinged on his approval. I still remember that when I was on the job market, I desperately wanted a job at Cornell. It was my first choice by far, and I constantly bored my friends with my worries and desires about employment. One night, I came home to a message on my machine that said, "This is Peter 
Katzenstein, calling from Cornell." I immediately called up my good friend Kurt Weyland, who has a German accent, and said, irate: "Now, that is really not funny. That is just plain mean." He said, "What are you talking about?" I said, "How can you make fun of me by pretending to be Peter Katzenstein?" He said, "I don't know what you are talking about." It was only then that I realized that the real Peter Katzenstein had actually called. I still remember his call telling me I got the job. I was driving north along the Great Pacific Highway in San Francisco on my way to work at the VA. It was just after dawn in California, and a magnificent sun was rising over the ocean. The phone rang and it was Peter. I was so excited that I had to pull the car over to the side of the road. When I hung up, I watched the early morning surfers and laughed uncontrollably. Watching them, I called Bob and told him the good news. He said, "My, well, it's always nice-and rarewhen things work out as they should. It won't always happen that way, so appreciate it while you can. And congratulations. I won't say I'm proud, because I am not your parent and that is not my role. But I am very, very happy for you."

My first year at Cornell, I taught a graduate international relations theory class with Peter, where I was absolutely the hardest and derives from many different areas for different people. But, professionally, in the end, what matters is not your status or your institution, but your students and your work." I am sure that different people would attach different values to those factors or add others such as community to that list. But the part that has been true for me in what he said relates to the importance of the work, not for any public purpose, but for the intrinsic worth of the intellectual exercise itself. Work helps give meaning and purpose to life. If you are lucky, it offers something concrete to grasp. Once you make it your own, it is yours-no matter what. No one can take it away. Others may not like it, but the work itself will wait patiently and never leave you or reject you or criticize you. It will absorb your time and your energy and your heart and your soul, and, in return, it will make your mind an interesting place in which you can live and feel at home, providing comfort and interest when everything outside is dark and no one has come to your door. And, if you are lucky, work can create a more interesting place for other interesting people to visit as well.

What these gifted mentors of mine share is a particular combination of four essential characteristics: brilliance, humor, perceptiveness, and generosity. Each of them, in their own way, has

\section{Work helps give meaning and purpose to life. If you are lucky, it offers something concrete to}

grasp. Once you make it your own, it is yours-no matter what. No one can take it away. Others may not like it, but the work itself will wait patiently and never leave you or reject you or criticize you. It will absorb your time and your energy and your heart and your soul, and, in return, it will make your mind an interesting place in which you can live and feel at home, providing comfort and interest when everything outside is dark and no one has come to your door. And, if you are lucky, work can create a more interesting place for other interesting people to visit as well.

working graduate student in the class. The class started at 7 p.m and often ran well past midnight. Peter was the only one in the room who could make it through without any nourishment or break. I felt very weak by comparison. And I did not like how that felt at all. But another of my most important lessons derived from that experience. Good work requires hard work over long periods of time. There is no substitute for simply putting one foot in front of the other, good days and bad, picking yourself up after you fall down, time and time again, to keep moving forward. I admit that this understanding followed closely on a lesson my own father instilled in me from childhood, which he no doubt picked up while fighting for four years in the Pacific in the Second World War: "Never give up. Never give in. Never surrender. And just because you are bleeding does not mean you don't provide covering fire for your true friends."

One of Peter's most important instructions to me came years later, when we were talking about how to be happy in academic life over the long haul. He said to me, "Self-esteem is important shared their insights and experience graciously with me over many years.

Bob Jervis once commented on children, saying, "Little kids, little problems; big kids, big problems." That observation provides an apt allegory for the problems one encounters in both life and academics. But the lessons these individuals have taught me and the ways in which they continue to instruct me as models have helped me to grow as a person, even more than as a scholar, in ways I never could have imagined when I first encountered them. My good friend and mentor Leda Cosmides, mother of evolutionary psychology, once told me that the only real comparative advantage that women have is that they get to love people in ways that don't threaten them. I am not sure I believe that, or that life is so simple. What I do know is that Bob, Bruce, and Peter, by nurture and through example, continue to expand my capacity to care about people and things in ways that continue to surprise, enlighten, delight, and comfort me. 


\section{American Political Science Association}

\section{Political Science Journals at Your Fingertips Individual JSTOR Access for APSA Members}

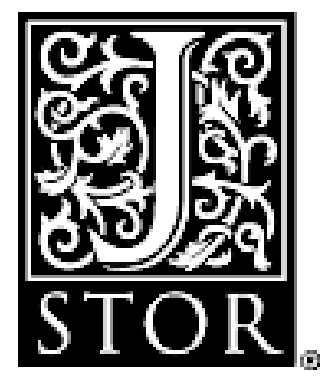

Looking for instant access to back issues of the APSR, PS, Perspectives, AJPS, AJIL or PSQ? Whether in the office, at home, or in the field, look no further than Individual APSA Member Access to JSTOR.

Did you know that APSA provides members direct access to a growing online collection of political science journals for only $\$ 25.00$ per year? A JSTOR individual subscription will give you access to the full electronic archives (all volumes ever published, up until 3 years ago) of the American Political Science Review, PS: Political Science and Politics, and Perspectives on Politics.

In addition to the APSA journals, the subscription gives you online access to several other political science journals, including the American Journal of Political Science, the American Journal of International Law, and Political Science Quarterly.

\section{APSA members: Subscribe to individual JSTOR access by logging into the APSA website at www.apsanet.org or by calling APSA Member Services at 202.483.2512.}

